\title{
A recepção das obras de Jorge Amado na China
}

\author{
Zhang Jianbo
}

Resumo: Na literatura brasileira, e também na literatura traduzida na China, Jorge Amado (19122001) é uma das referências obrigatórias. O autor escreveu mais de 30 livros ao longo de 70 anos, tendo tido 15 de seus títulos traduzidos para o chinês. Foi o primeiro escritor brasileiro a ser publicado em chinês, após a fundação da República Popular da China, em 1949. Com tantas obras traduzidas, Jorge Amado passou a ser muito "amado" pelos chineses. E é ainda boje o escritor brasileiro mais traduzido e, por conseguinte, a figura mais importante na difusão da cultura brasileira na China. No entanto, a tradução das obras de Jorge Amado na China não foi determinada primeiramente por uma ótica literária, mas sim política e ideológica. Na qualidade de membro do Partido Comunista do Brasil, as causas defendidas nas obras do escritor brasileiro eram aplaudidas pelo jovem governo comunista chinês nos anos 1950, quando Jorge Amado foi apresentado aos chineses como "lutador da paz", em vez de escritor. Devido à realidade sócio-histórica e cultural na China, a tradução de suas obras não foi contínua. Ela ocorreu basicamente em dois momentos significativos: na primeira metade dos anos 1950 e nos anos 1980, o que será apresentado neste artigo. Do ponto de vista literário, no entanto, essa segunda fase de tradução, na década de 1980, é a mais importante, uma vez que a ideologia política deixou de ser o critério principal na traducão de escritores estrangeiros na China, e assim o charme singular das obras de Jorge Amado tornou-se o "passaporte" para sua entrada na Cbina.

Palavras chave: Jorge Amado, Tradução, China

\section{Introdução}

No dia 7 de agosto de 2001, a maior agência oficial de notícias da China, Agência Xinhua, emitiu uma notícia em seu site ${ }^{1}$ :

\footnotetext{
1 Disponível em: <http://news.xinhuanet.com/st/2001-08/07/content_16608.htm>. Acesso em: 01
} outubro 2012. 
Jorge Amado, famoso romancista brasileiro, faleceu

Aos 88 anos de idade, o famoso romancista brasileiro, Jorge Amado, vítima de diabetes, faleceu em um hospital local da cidade de Salvador, Brasil, no dia 6 de agosto, por volta das $19 \mathrm{~h}$ (hora local). Amado foi um dos escritores brasileiros com maior projeção internacional. Em 1931, aos 19 anos de idade, publicou seu primeiro romance, O país do carnaval. Começou a ficar conhecido depois de dois anos, com o seu segundo livro, Cacau. Suas obras principais incluem romances como Suor, Mar Morto, Capitães da Areia, O Cavalheiro da Esperança, O Mundo da Paz, Tenda dos Milagres, Tieta do Agreste. Escreveu também poemas (como os reunidos em $A$ Estrada do Mar), peças teatrais (como $O$ Amor do soldado) e relatos históricos (como $A$ vida de Luis Carlos Prestes). As obras de Jorge Amado descrevem os mais diversificados aspectos da sociedade brasileira. Foram traduzidas para 48 línguas e publicadas em 53 países, o que lhe deu o título de "romancista brasileiro mais vendido" (Tradução minha).

A notícia não era grande, contava apenas 286 caracteres em chinês, mas foi relevante, por ter sido emitida pela agência estatal da China, e funcionou como mais uma apresentação, ainda que resumida, do escritor brasileiro aos chineses. $\mathrm{Na}$ notícia, os títulos de todos os seus livros foram traduzidos para o chinês, mesmo aqueles que não tinham ainda versão chinesa.

Jorge Amado é considerado o romancista brasileiro do povo, com o seu estilo próprio de narração: suas histórias quase sempre focalizam personagens marginalizados na sociedade, trabalhadores rurais explorados, meninos de rua, pescadores, marinheiros etc., que conseguem por vezes promover revoluções em seu ambiente. $\mathrm{O}$ rigor da língua nunca foi sua maior preocupação nas estórias contadas, pelo contrário, o autor sempre privilegiou a fluidez do discurso, a fala do povo, como ela realmente é.

Em 2012, os 100 anos de nascimento do escritor brasileiro Jorge Amado foi celebrado na Universidade de Macau, no âmbito da "Semana da Cultura Brasileira: A Bahia te espera!", com palestras sobre a obra de Jorge Amado e mostra do filme Capitães da Areia, adaptado do romance amadiano Capitães da Areia. O filme foi realizado por sua neta, Cecília Amado. Quatro meses depois, em março de 2013, ocorreu ainda em Macau o evento "Rota das Letras", que incluiu uma exposição sobre Jorge Amado, trazida pela filha do escritor, Paloma Amado, que fez uma apresentação sobre a vida e a ficção de seu pai, além de suas relações com a China.

Este trabalho tem por objetivo apresentar uma pesquisa historiográfica acerca da tradução e da introdução das obras de Jorge Amado na China. Buscará verificar as razões pelas quais essas obras foram "importadas" pelo novo governo comunista chinês, o porquê da interrupção de sua tradução entre as décadas de 
1950 e 1980 (e aqui não se pode deixar de mencionar o período de 1966 a 1976, anos da Revolução Cultural na China). Vai verificar também a retomada (a recuperação da vitalidade) da tradução das obras de Jorge Amado a partir do final dos anos 1970, e pretende levantar possíveis motivos que justifiquem por que, nos últimos 20 anos, a tradução e publicação das obras de Amado para o chinês não continuou num movimento ascendente, não sobressaiu no mercado da literatura estrangeira traduzida na China.

\section{1. $O 1^{\circ}$ momento importante da tradução das obras de Jorge Amado na China}

A tradução das obras de Jorge Amado na China não foi contínua, em função de particularidades históricas no desenvolvimento social da China, na evolução ideológica da sociedade chinesa. Existem dois momentos importantes no que se refere à tradução das obras de Jorge Amado na China. O primeiro momento ocorreu no início dos anos 1950, e o segundo sucedeu nos anos 1980.

\subsection{Ambiente Histórico}

O primeiro momento não surgiu por acaso, porque foi em 1949 que terminou na China a guerra civil, da qual resultou a fundação da República Popular da China, cujo "regime vermelho" fazia parte dos elos mais frágeis da corrente do comunismo internacional. A Segunda Guerra Mundial dividiu o mundo em dois grupos antagônicos: o capitalista e o comunista. Logo após a II Guerra Mundial, teve início a "guerra fria", que não era uma guerra convencional, mas sim um conflito primeiramente político e, consequentemente, econômico, ideológico e cultural entre as duas maiores nações da época, os Estados Unidos e a União Soviética, que lideravam seus respectivos grupos de países colaboradores. A China de então aderiu ao "grupo comunista", liderado pela União Soviética. Foi uma opção política e ideológica do país e, ao mesmo tempo, uma opção pragmática para o futuro do jovem Partido Comunista da China, que tinha que contar com o apoio providenciado pela União Soviética. Na altura, o novo regime vermelho chinês se encontrava numa conjuntura internacional muito complicada e enfrentava muitos desafios: mesmo que ganhasse a guerra civil, as forças contrárias do Partido Nacionalista da China continuavam existindo em Taiwan, que fica separado do continente chinês pelo Estreito de Taiwan, onde navegavam ainda porta-aviões norte-americanos. Por outro lado, concluída a guerra civil, a estagnação econômica e social pairava sob o país antigo, que carecia de meios para promover o desen- 
volvimento. Enquanto adotava o sistema político socialista, a China se alinhava à ideologia socialista com outros países "camaradas".

\subsection{A tradução na China do início do Século XX: uma releitura teórica}

André Lefevere em Translation, Rewriting and the Manipulation of Literary Fame (1992) formulou três termos: patronagem, ideologia e poética, que são capazes de manipular as atividades da tradução. Lefevere define ideologia como sendo "rede de forma, convenção e crença que determina nossas ações"2 e vê a patronagem como sendo ideologicamente orientada.

A ideologia tem funcionado como uma "mão invisível" nas atividades da tradução. Para Lefevere (1992), "Tradução é, de certeza, uma reescrita de um texto original. Toda reescrita, qualquer que seja sua intenção, reflete certa ideologia e poética, e manipula a literatura para funcionar, de certa maneira, em determinada sociedade."’ Portanto, a tradução é determinada por dois fatores básicos: a ideologia e a poética dominantes na cultura de chegada. A ideologia dita a seleção de tradução e as estratégias de tradução.

No caso da China, cuja política cultural começou a sofrer mudanças após a fundação do novo regime vermelho, foi gradualmente abandonada a atitude mais aberta e tolerante para com as culturas exteriores, que era uma atitude dominante na $1^{a}$ metade do século XX, quando a China passou por grandes transformações sociais: invasão dos países ocidentais (1840-1901), derrubada da monarquia feudal, e, posteriormente, a invasão dos japoneses (1937-1945). A introdução das mais variadas culturas estrangeiras na China do início do século XX, consideradas mais modernas e avançadas, tinha como objetivo, em termos ideológico-culturais, influenciar e inspirar uma renovação cultural na sociedade chinesa. Esse período, portanto, foi marcado por notável prosperidade e diversidade cultural, e coincide com a introdução de milhares de obras de escritores europeus e americanos.

A partir de 1949, foi adotada na China uma posição mais antagônica e repulsiva contra as culturas ocidentais, especialmente as culturas modernas, devido à hostilidade manifestada entre diferentes grupos ideológicos. No início dos anos 1950, a tradução de obras literárias estrangeiras, principalmente aquelas

2 [the grillwork of form, convention and belief which orders our actions.] (LEFEVERE, 1992a, p. 16).

3 [Translation is, of course, a rewriting of an original text. All rewritings, whatever their intention, reflect a certain ideology and a poetics and as such manipulate literature to function in a given society in a given way.] (LEFEVERE, 1992, p. vii). 
ideologicamente compatíveis com a própria literatura nacional, foi incorporada na construção da literatura nacional chinesa.

Em 1951, teve lugar em Pequim a "1 ${ }^{a}$ Reunião de Trabalho da Tradução", em que participaram os maiores especialistas chineses da área literária e da tradução. Na China, depois da transformação editorial que ocorreu nos anos 80 do século XX, o mercado veio a desempenhar um papel cada vez mais relevante na publicação, mas, antes disso, as opiniões de especialistas do meio cultural eram sempre predominantes, e, ao mesmo tempo, esses especialistas eram também muito influenciados pela política, ou seja, muitos deles pertenciam ao regime comunista da China. Retomando tópicos ideológicos na tradução, pode-se entender que, nos anos 1950, os fatores ideológicos vinham principalmente do governo e de especialistas.

Para Even-Zohar, um sistema sociossemiótico pode ser concebido como uma estrutura aberta e heterogênea que se configura como um polissistema, ou seja, um sistema múltiplo composto de várias redes simultâneas de relações, um conglomerado de sistemas interdependentes estratificados hierarquicamente em função das relações intra- e inter-sistêmicas dos seus elementos (EVEN-ZOHAR, 1990, p. 12; GENTZLER, 1993, p. 115).

No artigo "A interação do texto traduzido com o sistema receptor: a teoria dos polissistemas", Else Vieira informa que Even-Zohar afirmava que todo contexto sociocultural se constitui de diferentes sistemas que interagem entre si disputando um lugar hegemônico. Ao mesmo tempo, cada um destes sistemas se compõe de outros menores que se comportam da mesma maneira. Segundo essa concepção, o processo tradutório não se reduziria a uma simples transmissão de informações entre uma cultura e outra. A tradução deve ser considerada como parte integrante do sistema literário que sofre uma série de intervenções, tanto internas quanto externas e em constante competição pela hegemonia (VIEIRA, 1996, p. 125).

De acordo com Even-Zohar, o sistema mais privilegiado ou mais centralizado está no centro do polissistema, porém essa "escolha" cabe ao sistema sociocultural dominante e, os sistemas que ficam fora do centro são relativamente menos importantes e instáveis, mas dão, em conjunto, dinamismo à teoria dos polissistemas. A contribuição de Even-Zohar serviu para colocar os Estudos da Tradução na história da cultura, em vez da linguística ou da pedagogia. A literatura traduzida, de acordo com a Teoria dos Polissistemas, interfere e influencia a literatura de chegada. Em 1954, realizou-se a "Reunião de Trabalho Nacional da Tradução Literária", a partir da qual a tradução de literaturas estrangeiras veio a fazer parte do projeto cultural da China. Esta reunião teve exatamente o objetivo claro de introduzir, via tradução, outras culturas na cultura chinesa. 


\subsection{Obras de Jorge Amado entram na China}

Um dos principais objetivos das atividades de tradução na China, nos anos 1950, era a introdução ampla e completa das obras literárias da União Soviética. As obras literárias da Europa e dos Estados Unidos, por sua vez, eram alvos certos de censura, o que tornou sua introdução muito restrita, limitando-se às literaturas clássicas do século XIX, particularmente aquelas que criticavam a opressão de classes economicamente inferiores e os conflitos entre etnias. Havia interesse também na tradução literária de autores dos países socialistas do Leste Europeu, que eram países membros do partido comunista que compartilhavam a mesma ideologia socialista; e também em autores de outros países da Ásia, da África e da América Latina, considerados países do terceiro mundo, que alimentavam o mesmo desejo de independência ou de prosperidade.

No contexto dos escritores da América Latina, os dois que exerceram maior influência sobre os chineses foram o poeta chileno Pablo Neruda (1904-1973) e o romancista brasileiro Jorge Amado (1912-2001), por serem ambos membros do partido comunista. As posturas políticas evidenciadas em suas obras foram certamente os maiores motivos que os levaram à China.

Em 1951, Jorge Amado recebeu o Prêmio Stalin da Paz entre os Povos, tornando-se uma espécie de embaixador cultural comunista do Brasil. Foi justamente nesse ano que Jorge Amado foi apresentado, na China, pela revista Conbecimentos Mundiais, em artigo intitulado "O Lutador da Paz no Brasil: o Poeta Jorge Amado".

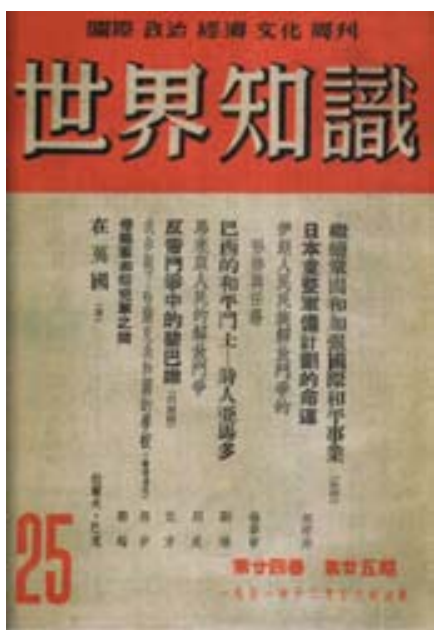

[Figura 1. Capa da Revista Conbecimentos Mundiais, 50, 1951] 


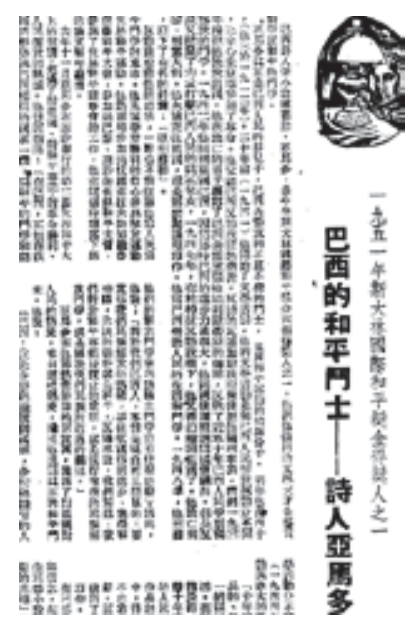

[Figura 2. Liu, Huai. "O Lutador da Paz no Brasil: Poeta Jorge Amado".

Revista Conbecimentos Mundiais, 1951]

A revista Conhecimentos Mundiais foi fundada pelo Partido Comunista e teve sua primeira edição na China em 1934, quando o Nordeste do país foi ocupado pelo Japão fascista, que alimentava ainda a ambição de ocupar toda a China. Nessa época, o Partido Nacionalista da China, que estava no poder, adotava uma política tolerante para com a entrada beligerante dos japoneses, mas muito severa e rígida para com o Partido Comunista da China, deixando todo o país imerso numa situação de caos. Nascida naquela época dura, a revista reforçou suas tendências esquerdistas. Além de difundir informações e conhecimentos gerais sobre todo o mundo, a revista dedicou boa parte de seus artigos à avaliação da conjuntura internacional, à revelação de ambições e conspirações de países fascistas e ao apelo da união de todos os povos sócio-economicamente oprimidos.

Veja-se como o escritor brasileiro foi apresentado na abertura do artigo:

Jorge Amado dedicou todo o seu talento literário à luta pela paz. Ele é um bom filho do povo brasileiro, enquanto lutador invencível do Partido Comunista do Brasil e ativista da paz mundial (minha tradução). ${ }^{4}$

O perfil de Jorge Amado, como escritor comunista, foi nitidamente traçado nesta breve apresentação: os chineses o viam, nessa época, essencialmente como uma figura política. Sua obra era avaliada, nesse contexto, sobretudo por seu posi-

4 LIU, Huai. "O Lutador da Paz no Brasil: o Poeta Jorge Amado”. Conbecimentos Mundiais, 1951. 
cionamento ideológico, e não por seus valores estético-literários. Esse perfil ideologicamente marcado de Jorge Amado foi reforçado pela ideologia dominante da China de então, que enfrentava ainda muitos "inimigos" capitalistas, tanto internos quanto externos, e o socialismo chinês buscava se fortificar com a solidariedade de companheiros de luta. A carreira profissional de Jorge Amado foi interessante para a literatura do novo regime chinês, e a introdução de romances do escritor brasileiro poderia fortalecer a ideologia socialista chinesa, além de enriquecer a própria literatura local, uma vez que Jorge Amado já era um escritor de sucesso, enquanto membro do Partido Comunista do Brasil.

Se no artigo da revista Conhecimentos Mundiais (1951) Jorge Amado foi apresentado inicialmente como uma figura política para os leitores chineses, um ano depois ele é apresentado como romancista pela revista Literatura do Povo, que publicou o $22^{\circ}$ parágrafo do primeiro capítulo do volume I do romance $O s$ Subterrâneos da Liberdade (o título do romance se manteve como o do parágrafo publicado em chinês).

Vale lembrar que a revista Literatura do Povo inicia suas atividades em 1949, e é considerada uma das publicações mais importantes da literatura contemporânea chinesa. Como a revista fica diretamente subordinada à Associação Chinesa de Escritores, ela é tida também como fruto da institucionalização da ideologia literária do regime comunista chinês.

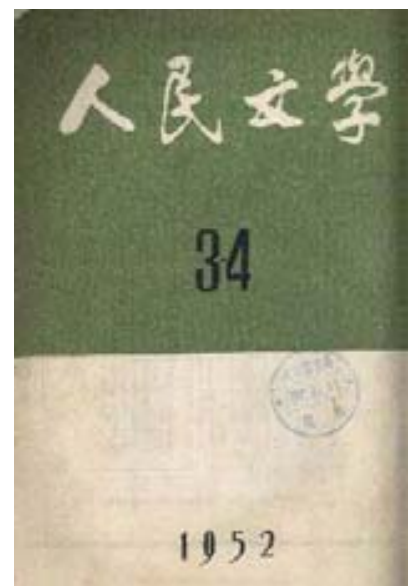

[Figura 3. Capa da revista Literatura do Povo, edição n. 34, 1952]

5 Traduzido do russo para o chinês pelo tradutor Chen Diyong. 
Mas por que terá sido traduzido exatamente o $22^{\circ}$ parágrafo do primeiro capítulo do volume I de um romance tão extenso? A linguagem nesse parágrafo será muito mais bonita? Essa passagem terá maior valor literário para os leitores chineses?

\subsection{O que se traduziu de Jorge Amado na China: escolha de textos}

No que diz respeito à seleção de textos a serem traduzidos e de estratégias de tradução, como todo texto é escrito para certo objetivo e deve servir ao mesmo tempo para esse objetivo, é crucial para o tradutor conhecer a razão por que o texto será traduzido e saber a função do texto a ser traduzido. A primeira função da tradução consiste na função social, e não na função linguística, como Lefevere (1992, p. 39) afirma: "Se considerações linguísticas entrarem em conflito com considerações de natureza ideológica ou poética, as últimas tendem a vencer. $\mathrm{Na}$ seleção de textos a serem traduzidos, é a ideologia dominante da sociedade da língua alvo que ocupa a posição mais importante porque, desde patrocinador(es) a grupos de leitores, quase todos ficam alinhados à ideologia dominante".

Um termo importante utilizado por Lefevere no âmbito dos estudos da tradução é patronagem, que pode ser entendida como o poder exercido por pessoas e instituições, tais como partidos políticos, editores, jornais, revistas, televisão etc., que determinam o que será permitido que se leia, escreva ou reescreva, em termos de literatura. Os chamados patronos preocupam-se com a ideologia da literatura, em vez de se deterem em sua poética, e também tentam regular a relação entre o sistema literário e os outros sistemas que formam em conjunto a sociedade e a cultura. Se não conseguem controlar a escrita, buscam pelos menos controlar os órgãos responsáveis por sua distribuição: academias, censores, revistas críticas ou estabelecimentos de ensino (LEFEVERE, 1992, p. 15). Segundo Lefevere, “a aceitação da patronagem implica que escritores e reescritores trabalhem dentro dos parâmetros estabelecidos por seus patrocinadores, e que estejam dispostos e sejam capazes de legitimarem tanto o status quanto o poder daqueles patrocinadores" (LEFEVERE, 1992, p. 18).

No caso da tradução das obras de Jorge Amado na China, durante o $1^{\circ}$ momento importante, o patrocinador era sempre o governo. O parágrafo traduzido descreve a caça aos comunistas feita pelos policiais a uma "oficina" dos comunistas, que no romance é uma casa de impressão onde comunistas se reúnem. Durante todo o conflito, os comunistas, apesar de acabar sendo presos, se comportam como heróis e não cedem nem um passo aos inimigos. A luta foi intensificada e a coragem dos camaradas comunistas foi destacada na tradução. No caso da adoção 
de estratégia de tradução, ganha mais peso a ideologia individual do tradutor, que é o agente mais importante que dá forma à ideologia carregada no texto traduzido. No entanto, o patrocinador influencia sempre o tradutor, que deve seguir as exigências estabelecidas pelo patrocinador para as atividades de tradução.

A tradução das obras de Jorge Amado na primeira metade dos anos 50 do século XX reflete justamente a função dos fatores ideológicos e de patronagem nas atividades de tradução que aconteceram na China. Na nota da tradução de São Jorge dos Ilhéus, o tradutor Zheng Yonghui (1956, p. 423) escreveu:

Estes três romances (Terras do Sem-Fim, Seara Vermelha e São Jorge dos Ilhéus) descreveram três fases da história do povo brasileiro: Terras do Sem-Fim relatava a história em que proprietários rurais disputaram terras e reservas de mata, expulsando e matando as pessoas pobres; São Jorge dos Ilhéus contava a história em que exportadores de cacau, na qualidade de "agentes" dos imperialistas norte-americanos e alemães, conquistaram terras aos proprietários rurais, nos anos 20 e 30 do século XX; Seara Vermelha descrevia a vida extremamente miserável das pessoas pobres que tinham perdido terra ou emprego. (tradução minha)

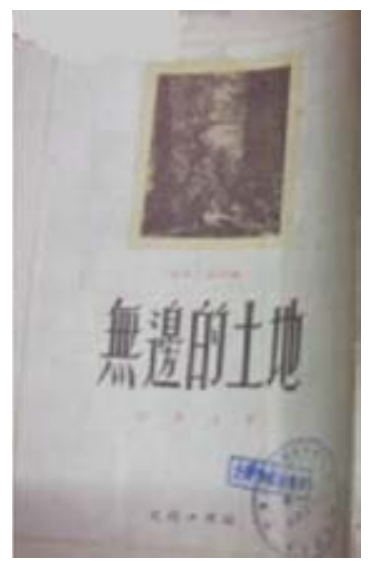

[Figura 4. Jorge Amado. Terras do Sem-Fim, tradução de Wu Lao, Editora de Cultura e de Trabalho, 1953] 


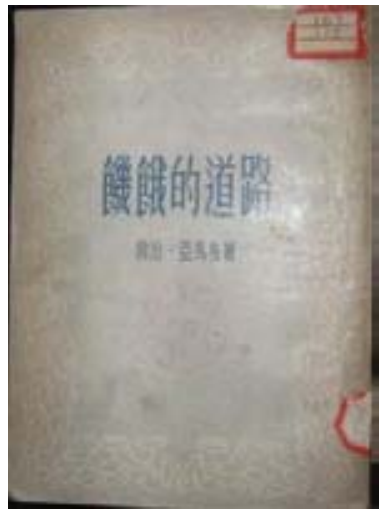

[Figura 5. Jorge Amado. Seara Vermelha, tradução de Zheng Yonghui, Editora Pingming, 1954]

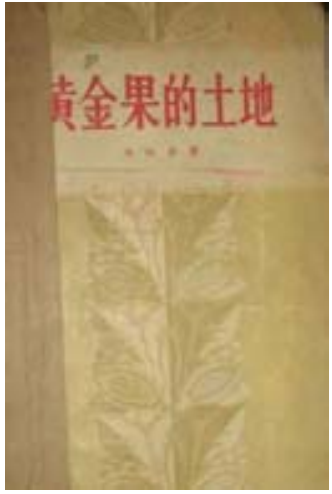

[Figura 6. Jorge Amado. São Jorge dos Ilhéus, tradução de Zheng Yonghui, Editora Pingming, 1956]

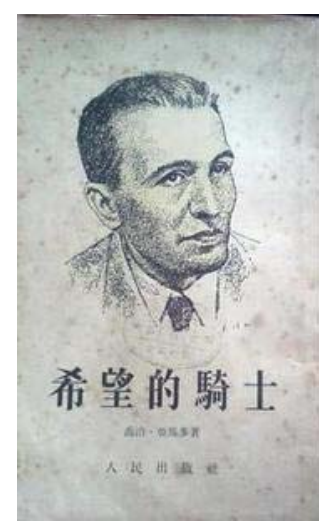

[Figura 7. Jorge Amado. O Cavalheiro da Esperança, tradução de Wang Yizhu, Editora do Povo, 1953] 
Nos primeiros romances amadianos traduzidos, destacaram-se o conflito entre proprietários rurais e pobres e imperialistas. As posturas políticas que o autor evidenciou nas obras, assim como sua aproximação proletária, eram aplaudidas pelo jovem regime vermelho chinês e até foram intensificadas pela tradução.

Durante este período, não apenas as obras de Jorge Amado entraram na China através da tradução, mas também o próprio escritor brasileiro, que visitou a China por duas vezes. A primeira visita ocorreu em março de 1952, depois de o escritor ter sido expulso pelo governo francês por motivos políticos em 1950. Jorge Amado passou a morar na Tchecoslováquia e, nos anos seguintes, viajou pelo Leste Europeu, visitando a União Soviética, a Mongólia e a China. Jorge Amado teve ainda um encontro com Wu Lao, o tradutor de Terras do Sem-Fim durante sua visita à China. Cinco anos depois, em julho de 1957, o escritor pisou mais uma vez o território da China. Tal como na primeira visita, Jorge Amado foi bem recebido pelo governo chinês.

\subsection{Fim do $1^{\circ}$ momento da tradução das obras de Jorge Amado}

Em 1956, teve lugar o XX Congresso do Partido Comunista da União Soviética, em que o secretário-geral do Partido, Nikita Khrushchev, fez o famoso Discurso Secreto, denunciando asperamente a política de seu antecessor, Stalin. Foram criticados também o culto da personalidade de Stalin e os crimes cometidos por ele e seus colaboradores. O XX Congresso do Partido Comunista da União Soviética gerou uma grande confusão no mundo comunista, que, durante anos de propaganda, fora convencido da grandeza do próprio Stalin e do socialismo empreendido por todo o mundo comunista liderado por ele. Foi a partir daí que se verificou a divergência e o consequente afastamento entre os partidos comunista da China e da União Soviética. A confusão que o XX Congresso do Partido Comunista da União Soviética gerou se estendeu ao Partido Comunista do Brasil, do qual se afastou Jorge Amado. A introdução de livros do escritor na China ficou, de certa maneira, afetada pelo cenário internacional.

Depois de 1956, só foi traduzido São Jorge dos Ilhéus do francês (em 1956) e foram reeditados Seara Vermelha (em 1956 e 1957) e Terras do Sem-Fim (em 1958) por diferentes editoras; nenhuma tradução nova foi feita no final dos anos 1950. Esta redução não se limitava apenas à tradução das obras de Jorge Amado. Na primeira metade da década de 1950, como já foi dito, a China adotava uma política cultural de repulsa contra as culturas européias e norte-americanas, mas as culturas de países do grupo socialista eram aplaudidas e vastamente introduzidas, resultado da função da ideologia política dominante, segundo a qual a introdução de todas 
as obras de escritores estrangeiros, além de manter e destacar as características nacionais da própria literatura chinesa, tinha que servir para solidificar sua base e natureza socialista. Buscou-se na China uma harmonia entre o socialismo e o nacionalismo na introdução de literaturas estrangeiras, que não poderia prejudicar a independência da literatura nacional.

Contudo, a ênfase demasiada na analogia ideológica política passou a constituir o único critério na introdução de literaturas estrangeiras; por exemplo, a postura política de certo escritor e a ideologia política transmitida em suas obras tornaram-se preocupações maiores na introdução e tradução de literaturas estrangeiras. Em breve, o grande fluxo das obras traduzidas, sobretudo da União Soviética, começava a prejudicar a ideologia nacional chinesa. Surgiu assim um círculo vicioso: quanto mais literaturas socialistas estrangeiras eram introduzidas no país, menos independente e marcante tornava-se a literatura nacional. Foi nesse contexto interno que o governo e os literatos da China começaram a reajustar a introdução de literaturas estrangeiras. O reajustamento se traduzia, de fato, na interrupção das traduções, a partir de 1955.

\section{2. $\mathrm{O} 2^{\circ}$ momento importante da tradução das obras de Jorge Amado na China}

\subsection{Ambiente Histórico}

As obras de Jorge Amado deixaram de ser traduzidas na China a partir de 1955. Nos anos de 1966 a 1976, a China vivia a Revolução Cultural, ocasião em que Jorge Amado e outros escritores, tanto chineses quanto estrangeiros, foram acusados de burgueses e inimigos do país. A publicação de qualquer livro estrangeiro foi proibida na China e essa "lacuna" permaneceu por 10 anos.

A Revolução Cultural terminou em 1976, e, dois anos depois, a China desencadeou seu processo de reforma e abertura. O país já não enfrentava desafios de invasão política e militar, e a posição política do regime comunista era cada vez mais firme. Olhando para fora, os políticos e intelectuais chineses ficaram encantados com a prosperidade social, econômica e cultural do mundo ocidental e sentiram uma necessidade urgente de fazer alguma mudança dentro do país.

$\mathrm{Na}$ vertente cultural, os literatos chineses chegaram a livrar-se da limitação da ideologia política que reinava nos anos 50 , adquirindo uma visão muito mais ampla e abrangente. A partir do fim dos anos 70, as atividades culturais na China começaram a recuperar a vitalidade, que também se refletia no aumento da tradução de literaturas estrangeiras. Em 1977, a revista Literatura Mundial retomou 
suas atividades de publicação, o que foi visto como algo simbólico da recuperação da introdução de literaturas estrangeiras na China, porque, antes da Revolução Cultural, a Literatura Mundial era a única publicação chinesa que lidava com a introdução de teorias e obras literárias estrangeiras na China.

No início, a tradição durante os 17 anos $^{6}$ se manteve, mas pouco tempo depois, a introdução de literaturas modernas ocidentais despertou nos leitores a vontade de ler, e, nos tradutores, o entusiasmo por traduzir.

\subsection{Obras de Jorge Amado continuaram entrando na China}

\subsubsection{NA DÉCADA DE 1980}

Depois de um isolamento de mais de duas décadas, as obras de Jorge Amado passaram a atrair novamente a atenção dos literatos chineses. Lin Yi’an (2011) afirmou que, em 1978, a revista Literatura Mundial decidiu, além de traduzir obras de escritores latino-americanos que nunca tinham sido traduzidos na China, continuar traduzindo os escritores latino-americanos, cujas obras tinham sido tratadas de forma inadequada durante a Revolução Cultural. Mais uma vez, Pablo Neruda e Jorge Amado foram as primeiras escolhas. Outra decisão da revista Literatura Mundial não menos importante: as obras dos dois escritores teriam que ser traduzidas a partir das respectivas línguas-fonte, isto é, a China iria traduzir, pela primeira vez, as obras de Jorge Amado diretamente do português.

Graças à formação de tradutores de português a partir dos anos 1960, a China já contava com tradutores de português experientes nos anos 80 . Sun Cheng'ao, que era na época professor de português do Instituto de Línguas Estrangeiras de Pequim $^{7}$ e se dedicou depois aos estudos literários e culturais em língua portuguesa, foi uma das figuras mais influentes na diplomacia cultural da China. Outro tradutor que merece destaque é Fan Weixin, que trabalhou no Departamento de Português da Rádio Internacional da China e foi considerado, juntamente com Sun Cheng'ao, pioneiro na tradução das obras de escritores da língua portuguesa.

A convite da revista Literatura Mundial, Sun Cheng'ao iniciou a tradução de A Morte e a Morte de Quincas Berro D'água, que foi escolhido por Sun Cheng'ao e Lin Yi'an, editor da Literatura Mundial, pesquisador e tradutor da Academia Chi-

\footnotetext{
6 Na história literária chinesa, este espaço de tempo corresponde aos 17 anos, desde 1949, quando se fundou a República Popular da China, a 1967, início da Revolução Cultural.

7 A atual Universidade de Estudos Estrangeiros de Pequim.
} 
nesa de Ciências Sociais. As justificativas da escolha foram: Em primeiro lugar, a novela foi muito bem recebida no Brasil e Vinicius de Moraes elogiou a obra como a melhor novela da literatura brasileira; a novela foi considerada mais séria, ou seja, tem menos descrições eróticas, que manifestam uma existência exuberante em obras de Jorge Amado e a China dos anos 80 ainda era conservadora e não se habituava a esse estilo livre do escritor; a novela não é muito grande e o tamanho foi propício para se publicar em revista.

Concluída a tradução, a novela recebeu grandes elogios após a publicação em 1981. Quatro anos depois, a tradução saiu da revista Literatura Mundial e foi reeditada e lançada ao mercado pela editora Guangming Daily em 1985.

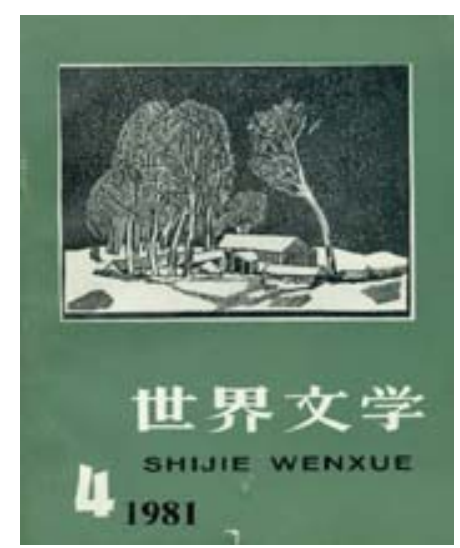

[Figura 8. Capa da revista Literatura Mundial, edição no 4, 1981]

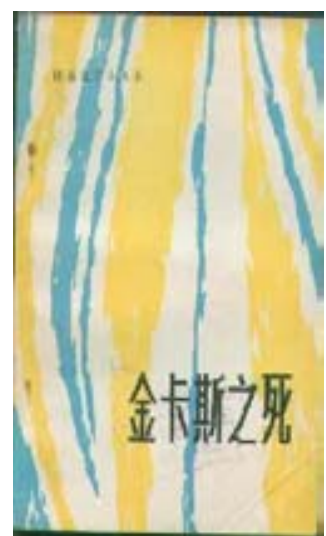

[Figura 9. Jorge Amado. A Morte e a Morte de Quincas Berro D 'água, tradução de Sun Cheng'ao, Editora Guangming Daily, 1985] 
O sucesso de $A$ morte e a morte de Quincas Berro D'água incentivou logo na China mais traduções de Jorge Amado: foram traduzidas nos anos 1980 mais nove obras do escritor, sendo que Gabriela, Cravo e Canela foi traduzida duas vezes: em tradução indireta, do espanhol, em 1984, e, diretamente do português, em 1985, ainda por Sun Cheng'ao.

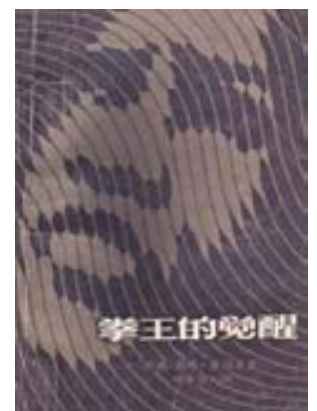

[Figura 10. Jorge Amado. Jubiabá, tradução de Zheng Yonghui, Editora do Povo de Hunan, 1983]

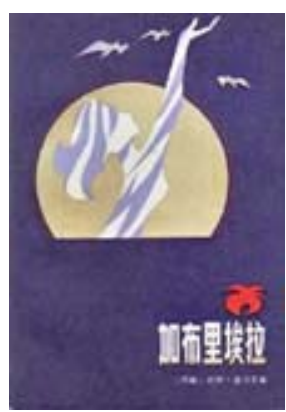

[Figura 11. Jorge Amado. Gabriela, Cravo e Canela, tradução de Xu Zenghui, Editora da Literatura e Arte Changjiang, 1984]

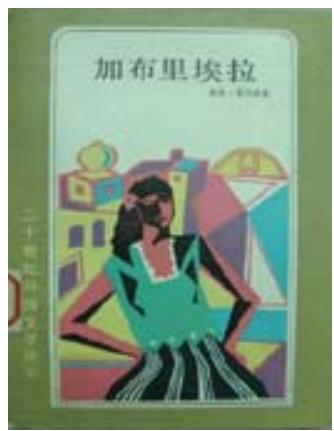

[Figura 12. Jorge Amado. Gabriela, Cravo e Canela, tradução de Sun Cheng’ao, Editora de Tradução e Publicação de Xangai, 1985] 


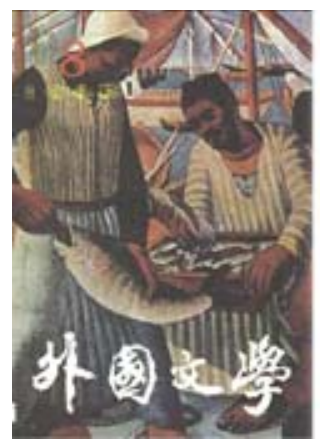

[Figura 13. Capa da Revista Literatura Estrangeira, 1985]

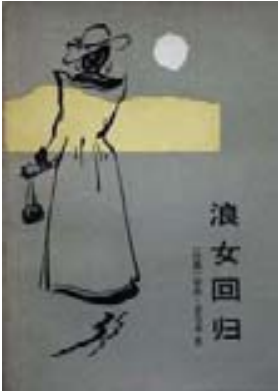

[Figura 14. Jorge Amado. Tieta do Agreste, tradução de Cheng Jingyong, Editora da Literatura e Arte Changjiang, 1986]

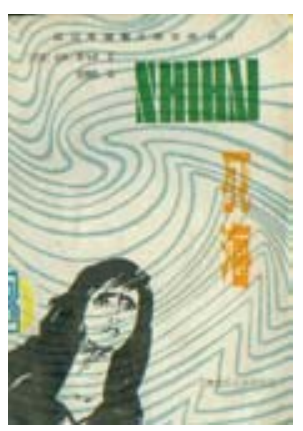

[Figura 15. Jorge Amado. Mar Morto, tradução de Fan Weixin, Editora do Povo de Heilongjiang, 1987] 


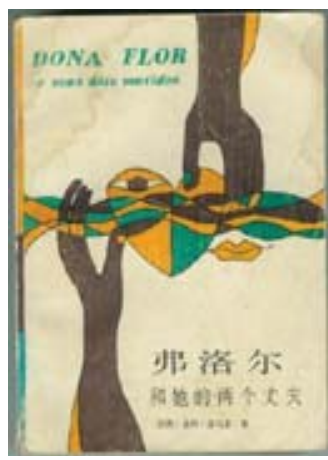

[Figura 16. Jorge Amado. Dona Flor e Seus Dois Maridos, tradução de Fan Weixin e Sun Cheng'ao, Editora do Povo de Yunnan, 1987]

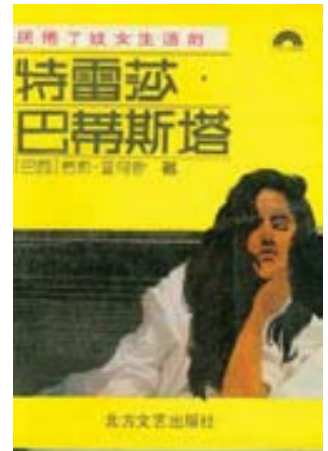

[Figura 17. Jorge Amado. Teresa Batista, Cansada de Guerra, tradução de Wen Hua, Editora da Literatura e Arte do Norte, 1988]

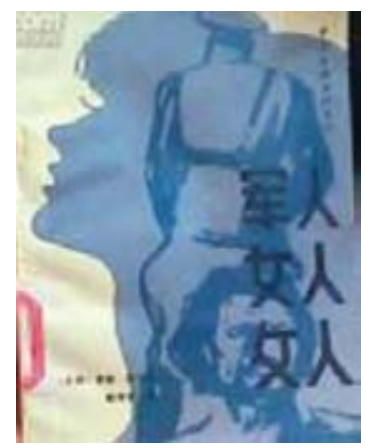

[Figura 18. Jorge Amado. Farda, Fardão e Camisola de Dormir, tradução de Chen Fengwu, Editora de Federação Literária Chinesa, 1989] 


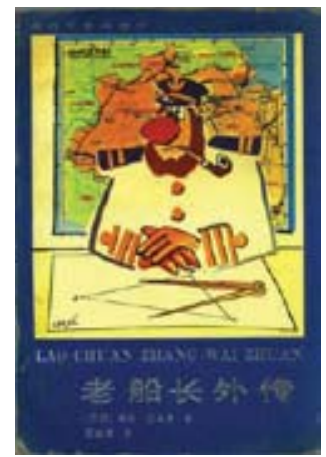

[Figura 19. Jorge Amado. Os Velhos Marinheiros, tradução de Fan Wenxin, Editora da Literatura e Arte de Huashan, 1989]

As posturas políticas do escritor deixaram de ser o critério principal e foi exatamente o charme das próprias obras o que chamou a atenção dos intelectuais no meio literário chinês. A ideologia política dominante nos anos anteriores parou de exercer tanta influência sobre a seleção de obras a serem traduzidas e houve a adoção de estratégias de tradução em que se evidenciava uma preferência cada vez mais literária e menos política.

Segundo Lin Yi'an (2011), Jorge Amado esteve em alta na China por longa temporada e teve mais sorte do que o poeta chileno Neruda, falecido em 1973. Os dois escritores foram distanciados dos leitores chineses durante a Revolução Cultural, mas as obras de Jorge Amado vieram a ser diretamente traduzidas do português para o chinês a partir dos anos 80 . Ele ainda chegou a visitar mais uma vez a China.

\subsubsection{NA DÉCADA DE 1990 E O FIM DO SEGUNDO MOMENTO}

Entrando na década de 90, a moda de Jorge Amado decaiu. Depois de Tocaia Grande, traduzido por Fan Weixin e Sun Cheng'ao em 1991, nenhum novo livro de Jorge Amado foi traduzido na China. No final dos anos 80, a Editora do Povo de Yunnan iniciou a compilação de "Coleção da Literatura Latino-americana", de que consta uma subcoleção chamada "Escritores Latino-americanos Falam sobre a Escrita". Esta subcoleção, que foi lançada no mercado nos anos 1990, inclui oito escritores da América Latina, inclusive Jorge Amado. O tradutor Sun Cheng'ao escreveu, com base em informações que lhe tinham sido dadas pelo próprio escritor, o Sou o Romancista do Povo em chinês, em que o escritor responde às perguntas sobre sua vida e sua ficção. 


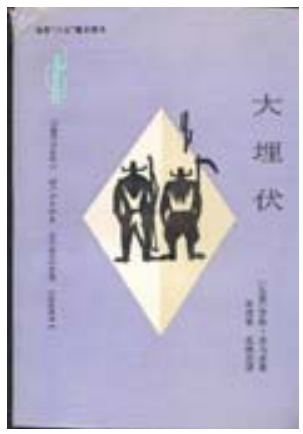

[Figura 20. Jorge Amado. Tocaia Grande, tradução de Sun Cheng'ao e Fan Weixin, Editora do Povo de Yunnan, 1991]

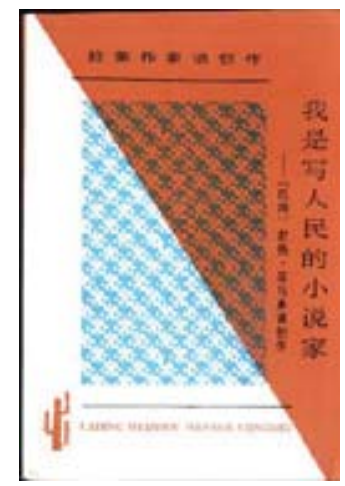

[Figura 21. Sun Cheng'ao. Sou o Romancista do Povo. Editora do Povo de Yunnan, 1997]

No século XXI, as obras de Jorge Amado pararam novamente de ser traduzidas, e só em 2008 a editora Yilin Press reeditou dois romances do escritor: Gabriela, Cravo e Canela e Dona Flor e Seus Dois Maridos, que são, para os leitores chineses, os dois melhores romances do escritor. 


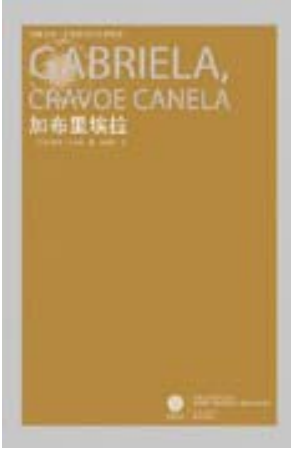

[Figura 22. Jorge Amado. Gabriela, Cravo e Canela, tradução de Sun Cheng'ao, Editora Yilin Press, maio de 2008]

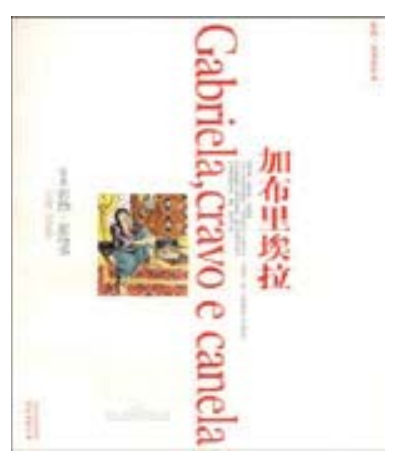

[Figura 23. Jorge Amado. Gabriela, Cravo e Canela, tradução de Sun Cheng'ao, Editora Yilin Press, junho de 2008]

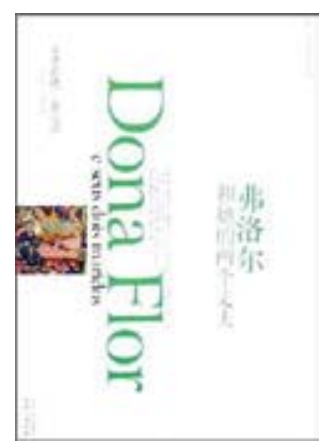

[Figura 24. Jorge Amado. Dona Flor e Seus Dois Maridos, tradução de Sun Cheng’ao e Fan Weixin, Editora Yilin Press, 2008] 
O segundo momento mais importe da tradução das obras de Jorge Amado terminou, de fato, em 1991, quando saiu a última tradução do romance Tocaia Grande.

Além de se relacionar estreitamente com a mudança do papel da ideologia política dominante na China, o surgimento e o desaparecimento dos dois auges da tradução das obras de Jorge Amado se devem ainda à transformação editorial da China. Como abordado acima, as editoras são os mais importantes patrocinadores das atividades de tradução. Desde a fundação da República Popular da China até o término da Revolução Cultural, as editoras eram extremamente poucas e todas eram estatais. Eram, portanto, mais governamentais do que culturais, ou seja, tinham pouca liberdade no exercício de atividades, que tinham que ser determinadas pelo governo que era, na época, o maior patrocinador de tradução. Apesar de haver mais editoras nos anos 1980, estas continuavam sendo estatais. Até os anos 80, a lucratividade não era o maior objetivo das editoras, e o governo se responsabilizava por perdas e ganhos. Bastava que as editoras cumprissem as "ordens" do governo, que escutassem especialistas do meio literário, tais como pesquisadores acadêmicos, professores e tradutores, que eram muito influenciados pela política. Pode-se dizer que foram os especialistas do meio literário que descobriam o charme das obras de Jorge Amado: a mistura cultural mestiça, o humor lúdico, o espírito folclórico baiano, o realismo mágico brasileiro e o imaginário libidinoso nordestino, entre outros. Depois dos anos 1990, o regime editorial sofreu mudanças e cada vez mais editoras se tornaram privadas e, para as editoras privadas, a lucratividade tornou-se cada vez mais importante. Antes da publicação de qualquer livro, faz-se uma pesquisa de mercado, o que nunca aconteceu nos 17 anos antes da Revolução Cultural. Seria corajoso, ou até perigoso, para uma editora, introduzir obras que pudessem não ser procuradas no mercado. Por razões mercadológicas, tem havido uma preferência para livros de língua inglesa, francesa, alemã, espanhola e japonesa, mas com menos destaque para a língua portuguesa. Perante tantas escolhas, muitos leitores eventuais de Jorge Amado desviaram seu foco de interesse.

\section{Conclusão}

A tradução das obras de Jorge Amado na China não aconteceu por acaso e tem condições ideológicas e históricas. Nos seus dois momentos importantes na China, 15 obras completas foram traduzidas de diversas línguas (russo, francês, espanhol e português) para o chinês. Com esta quantidade de obras conhecidas pelos leitores chineses, Jorge Amado é, sem nenhuma sombra de dúvida, o escritor brasileiro mais importante na difusão da literatura brasileira na China. 
O regime comunista chinês era recém-nascido na primeira metade dos anos 50 do século XX e era ao mesmo tempo membro do grupo de países socialistas. O governo chinês tinha motivos para defender a sua ideologia política socialista de eventuais ataques oriundos de ideologias "nocivas" ocidentais. Foi exatamente a ideologia política dominante dentro do país que determinou a seleção das obras de Jorge Amado para serem traduzidas. Como o governo comunista chinês detinha naquela altura quase todos os recursos estatais e sociais, ele próprio foi o maior patrocinador de todas as atividades de tradução que aconteceram no país, mesmo que essas atividades fossem praticadas por diversas editoras que, juntamente com especialistas do meio literário, tais como pesquisadores acadêmicos, professores e os próprios tradutores, exerciam também grande influência na tradução das obras de Jorge Amado na China.

Depois da Revolução Cultural, a China conheceu evidentes mudanças em aspetos sociais, econômicos e culturais. A partir dos anos 1980, a própria literatura passou a ganhar mais importância na introdução de escritores estrangeiros na China. Verificou-se a partir daí uma grande diversificação na seleção de escritores estrangeiros. Um grande fluxo de obras de Jorge Amado entrou na China nos anos 1980, quando o governo ainda era o maior patrocinador de traduções e o "modelo" de funcionamento da primeira metade dos anos 1950 se manteve. Uma diferença bastante visível reside no fato de que a ideologia política dominante veio a perder sua dominância majoritária a partir do final dos anos 1970. A transformação editorial sucedeu na China ao longo do seu desenvolvimento econômico e social, em que se manifestava a mudança de relações de poder. $O$ governo chinês deixou de ser o maior patrocinador de tradução e o mercado passou a desempenhar um papel cada vez mais relevante na introdução de obras de escritores estrangeiros. Foi nesse contexto que a tradução de literaturas estrangeiras na China se diversificou ainda mais em comparação com as décadas anteriores.

\section{Referências}

AMADO, Jorge. A Morte e a Morte de Quincas Berro D'água, tradução de Sun Cheng'ao. Pequim: Editora Literatura Mundial, 1981.

AMADO, Jorge. Dona Flor e seus dois maridos, tradução de Fan Weixin e Sun Cheng'ao. Kunmig: Editora do Povo de Yunnan, 1987.

AMADO, Jorge. Dona Flor e seus dois maridos, tradução de Fan Weixin e Sun Cheng'ao. Nanquin: Editora Yilin Press, 2008.

AMADO, Jorge. São Jorge dos Ilhéus, tradução de Zheng Yonghui. Pequim: Editora dos Escritores, 1956. 
AMADO, Jorge. Seara Vermelha, tradução de Zheng Yonghui. Xangai: Editora Pingming. 1954. AMADO, Jorge. Terras do Sem-Fim, tradução de Wu Lao. Xangai: Editora de Cultura e de Trabalho, 1953.

ANDRÉ, James St. History. In BAKER, Mona; SALDANHA, Gabriela (eds.). Routledge Encyclopedia of Translation Studies. Londres: Routdlege, 2009, $2^{\mathrm{a}}$ ed., pp. 133-136.

BASSNETT, Susan; LEFEVERE, André (Orgs.). Translation, history \& culture. Londres: Printer Publishers, 1990.

CHEN, Ming. Translation of Foreign Literature in Contemporary China: A Study from the Perspective of Manipulation Theory (1949-2008). Jinan: Universidade de Shandong, 2009.

EVEN-ZOHAR, Itamar. Polysystem theory. Disponível em: < http:/ / www.tau.ac.il/ itamarez /works/books/ez-pss1990.pdf>.

GENTZLER, Edwin. Contemporary Translation Theories. Londres e Nova Iorque: Routledge, 1993.

LEFEVERE, André. Translation, Rewriting and the Manipulation of Literary Fame. Londres e Nova Iorque: Routledge, 1992a.

SUN, Cheng'ao. Sou o Romancista do Povo. Kunmig: Editora do Povo de Yunnan, 1997.

VIEIRA, Else, R. P. "A interação do texto traduzido com o sistema receptor: a teoria dos polissistemas”. In: VIEIRA, Else, R. P. (Org.) Teorizando e contextualizando a tradução. Belo Horizonte: Faculdade de Letras da UFMG, Curso de Pós-Graduação em Estudos Linguísticos, 1996. pp. 124-137.

YAN, Xiao-jiang. "On the Role of Ideology in Translation Practice". In: US-China Foreign Language, v. 5, n. 4, 2007, pp. 63-65.

郭元增. 亚马多——巴西著名的“平民”作家. 拉丁美洲研究. 2002, (1). pp. 45-47. (GUO, Yuanzeng. "Amado: O Famoso Escritor Brasileiro do Povo". In: Estudos Latino-americanos, 1, 2002, pp. 45-47.)

林一安. 幸运的亚马多。中华读书报. 2011年03月02日,p. 19.

(LIN, Yi'an. "Amado: Escritor Brasileiro Sortudo". In: Jornal Chinês de Leitura, Mar 02. 2001, pp. 19).

刘淮. 巴西的和平斗士一一诗人亚马多。世界知识. 1951, (50). pp. 13-14

(LIU, Huai. "O Lutador da Paz: o Poeta Jorge Amado". In: Conhecimentos Mundiais, 50, 1951, pp. 14-14).

孙成敖. 从《加布里埃拉》看若热 - 亚马多小说的艺术鬼力。外国文学. 2001, (3). pp. 69-72.

(SUN, Cheng'ao. “O Charme de Romances de Jorge Amado: uma leitura de Gabriela, Cravo e Canela. In: Literatura Estrangeira, 3, 2001, pp. 69-72.)

孙成敖。难忘伟大的巴西 “民众”作家亚马多。环球时报。2001年8月10日, p. 17. (SUN, Cheng'ao. “O Grande Escritor do Povo, Amado é Inesquecível”. In: Global Times, Aug 10, 2001, pp. 17) 
孙成敖. 亚马多- - - 位写人民的小说家. 百科知识. $2002,(10)$. pp. 57-58.

(SUN, Cheng'ao. "Amado: Um Romancista Que Escreve o Povo". In: Conhecimento Enciclopédico, 10, 2002, pp. 57-58.)

孙艺风. 跨文化语境下的意识形态一一兼论翻译的功能与作用. 四川外语学院 学报. 2003, (06). pp. 108-113.

(SUN, Yifeng. "Ideologia num Contexto Cross-Cultural: Função e Papel de Tradução". In: Jornal Acadêmico do Instituto de Estudos Estrangeiros de Sicbuan, 6, 2003, pp. 108-113.)

万光. 访问亚马多. 人民日报. 1956, (10)

(WAN, Guang. "Uma Visita a Jorge Amado". In: Diário do Povo, 10, 1956)

王东风. 一只看不见的手-一论意识形态对翻译实践的操纵。中国翻译. 2003, (05). pp. 18-25.

(WANG, Dongfeng. "Uma Mão Invisível: Manipulação Ideológica em Práticas de Tradução". In: Jornal de Tradutores Chineses, 5, 2003. pp. 18-25.)

王锁英. 一部反映巴西人精神状态的小说. 外国文学. 1987, (12). pp. 88-89.

(WANG, Suoying. "Um Romance Que Reflete o Estado de Espírito dos Brasileiros". In: Literatura Estrangeira, 12, 1987, pp. 88-89.)

\section{Anexo: Obras de Jorge Amado traduzidas na China}

\begin{tabular}{|c|c|c|c|c|}
\hline Ano & Nome da Obra & Tradutor & Editora & Língua-fonte \\
\hline 1953 & Terras do Sem-Fim & Wu Lao & $\begin{array}{c}\text { Editora de Cultura } \\
\text { e de Trabalho }\end{array}$ & Inglês \\
\hline 1953 & $\begin{array}{l}\text { O Cavalheiro da Esperanca, a } \\
\text { Vida de Luís Carlos Prestes }\end{array}$ & Wang Yizhu & Editora do Povo & Russo \\
\hline 1954 & Seara Vermelha & Zheng Yonghui & Editora Pingming & Francês \\
\hline 1956 & Seara Vermelha & Zheng Yonghui & $\begin{array}{l}\text { Editora da Nova } \\
\text { Literatura e Arte }\end{array}$ & Francês \\
\hline 1956 & São Jorge dos Ilhéus & Zheng Yonghui & $\begin{array}{l}\text { Editora dos } \\
\text { Escritores }\end{array}$ & Francês \\
\hline 1957 & Seara Vermelha & Zheng Yonghui & $\begin{array}{l}\text { Editora dos } \\
\text { Escritores }\end{array}$ & Francês \\
\hline 1958 & Terras do Sem-Fim & Wu Lao & $\begin{array}{l}\text { Editora dos } \\
\text { Escritores }\end{array}$ & Inglês \\
\hline 1981 & $\begin{array}{l}\text { A Morte e a Morte de } \\
\text { Quincas Berro D'água }\end{array}$ & Sun Cheng'ao & $\begin{array}{c}\text { Editora Literatura } \\
\text { Mundial }\end{array}$ & Português \\
\hline 1983 & Jubiabá & Zheng Yonghui & $\begin{array}{l}\text { Editora do } \\
\text { Povo de Hunan }\end{array}$ & Francês \\
\hline 1984 & Gabriela, Cravo e Canela & Xu Zenghui & $\begin{array}{c}\text { Editora da Literatura } \\
\text { e Arte Changjiang }\end{array}$ & Espanhol \\
\hline
\end{tabular}




\begin{tabular}{|c|c|c|c|c|}
\hline 1985 & Gabriela, Cravo e Canela & Sun Cheng'ao & $\begin{array}{l}\text { Editora de Tradução } \\
\text { e Publicação de Xangai }\end{array}$ & Português \\
\hline 1985 & Cacau & Sun Cheng'ao & $\begin{array}{c}\text { Editora Literatura } \\
\text { Exterior }\end{array}$ & Português \\
\hline 1986 & Tieta do Agreste & Chen Jingyong & $\begin{array}{l}\text { Editora da Literatura } \\
\text { e Arte Changjiang }\end{array}$ & Russo \\
\hline 1987 & Mar Morto & Fan Weixin & $\begin{array}{l}\text { Editora do Povo } \\
\text { de Heilongjiang }\end{array}$ & Português \\
\hline 1987 & $\begin{array}{l}\text { Dona Flor e Seus } \\
\text { Dois Maridos }\end{array}$ & $\begin{array}{l}\text { Sun Cheng'ao } \\
\text { Fan Weixin }\end{array}$ & $\begin{array}{l}\text { Editora do Povo } \\
\text { de Yunnan }\end{array}$ & Português \\
\hline 1988 & $\begin{array}{c}\text { Teresa Batista, } \\
\text { Cansada de Guerra }\end{array}$ & Wen Hua & $\begin{array}{c}\text { Editora da Literatura } \\
\text { e Arte do Norte }\end{array}$ & Russo \\
\hline 1989 & $\begin{array}{l}\text { Farda, Fardão e } \\
\text { Camisola de Dormir }\end{array}$ & Chen Fengwu & $\begin{array}{l}\text { Editora de Federação } \\
\text { Literária Chinesa }\end{array}$ & Português \\
\hline 1989 & Os Velhos Marinheiros & Fan Weixin & $\begin{array}{l}\text { Editora da Literatura } \\
\text { e Arte de Huashan }\end{array}$ & Português \\
\hline 1991 & Tocaia Grande & $\begin{array}{l}\text { Sun Cheng'ao } \\
\text { Fan Weixin }\end{array}$ & $\begin{array}{l}\text { Editora do Povo } \\
\text { de Yunnan }\end{array}$ & Português \\
\hline 1992 & Terras do Sem-Fim & Wu Lao & $\begin{array}{l}\text { Editora de Tradução e } \\
\text { Publicação de Xangai }\end{array}$ & Inglês \\
\hline 1997 & Sou o Romancista do Povo & $\begin{array}{l}\text { Sun Cheng'ao } \\
\text { (Autor) }\end{array}$ & $\begin{array}{l}\text { Editora do Povo } \\
\text { de Yunnan }\end{array}$ & Português \\
\hline 2008 & Gabriela, Cravo e Canela & Sun Cheng'ao & Editora Yilin Press & Português \\
\hline 2008 & $\begin{array}{l}\text { Dona Flor e Seus } \\
\text { Dois Maridos }\end{array}$ & $\begin{array}{l}\text { Sun Cheng'ao } \\
\text { Fan Weixin }\end{array}$ & Editora Yilin Press & Português \\
\hline
\end{tabular}

